Bulletin of the Natural History Museum, 2017, 10: 45-56.

Received 04 Sep 2017; Accepted 23 Nov 2017.

doi: $10.5937 / \mathrm{bnhmb} 1710045 \mathrm{~N}$

UDC: 582.998.1(497.7); 582.998.3(497.7)

Original scientific paper

\title{
TWO NEW SPECIES FOR THE FLORA OF REPUBLIC OF MACEDONIA
}

\author{
MARJAN NIKETIĆ ${ }^{*}$, LJUPČO MELOVSKI ${ }^{2}$, VLADO MATEVSKI $^{2}$, \\ GORDANA TOMOVIĆ
}

${ }^{1}$ Natural History Museum, 11000 Belgrade, Serbia, e-mail: mniketic@nhmbeo.rs

${ }^{2}$ Institute of Biology, Faculty of Natural Sciences and Mathematics, Sts. Cyril and Methodius University, Arhimedova 5, 1000 Skopje, Republic of Macedonia, e-mail: melovski@pmf.ukim.mk; vladom@pmf.ukim.mk

${ }^{3}$ Institute of Botany and Botanical Garden, Faculty of Biology, University of Belgrade, 11000 Belgrade, Serbia, e-mail: gtomovic@bio.bg.ac.rs

During two botanical expeditions in the Republic of Macedonia in 2017 (Mts Šar Planina and Mt. Jakupica), two plants were found that are new for the flora of this country: Campanula wanneri Rochel in Mt. Jakupica and Carduus ramosissimus Pančić in Mts Šar Planina. The plant species habitats and phytogeographic importance of these new findings were discussed within the scope of their newly established distribution patterns in the Balkan Peninsula.

Key words: Campanula wanneri, Carduus ramosissimus, new records, Republic of Macedonia

\section{INTRODUCTION}

In the last decade, several articles were published regarding new taxa for the flora of the Republic of Macedonia (Matevski \& Teofilovski 2004, 2011, Matevski 2016, Niketić et al. 2014, Teofilovski 2011, 2017). Still, there are many areas/localities in Macedonia that, in botanical terms, are 
not well explored. Among them are the silicate parts of Mt. Jakupica, due to the fact that many botanists more frequently visited the attractive and higher limestone parts of the mountain. Some remote parts of Mts Šar Planina are also insufficiently studied. As a result, on these two mountains we discovered two new species for the flora of the Republic of Macedonia. In this article we present these new plants with their ecological preferences, as well as the phytogeographical importance of these new findings.

\section{MATERIAL AND METHODS}

Field surveys were carried out in Mt. Jakupica and Mts Šar Planina in July and August 2017 respectively, and identification of the collected plant material was performed by use of standard botanical literature. Distribution of the species in the Republic of Macedonia is presented according to the grid map with squares of $10 \times 10 \mathrm{~km}$, based on the Military Grid Reference System (MGRS) projection (Lampinen 2001). Collected plant material was stored in the Herbarium of the Natural History Museum in Belgrade (BEO) and the Herbarium of the Institute of Botany and Botanical Garden "Jevremovac", University of Belgrade (BEOU) (Thiers 2017, http://sciweb. nybg. org/ Science2/Index-Herbariorum.asp). Nomenclature followed Euro+Med Plantbase (http://ww2.bgbm.org/EuroPlusMed/query.asp).

\section{RESULTS AND DISCUSSION}

Campanula wanneri Rochel - CAMPANULACEAE (Fig. 1)

三Symphyandra wanneri (Rochel) Heuff.

When it was described by Rochel (1828), this species was primary included in the genus Campanula L. while later, Heuffel (1858) placed it into the genus Symphyandra A. DC. based on connate anthers in a tube surrounding the style at anthesis. In the recent database (Castroviejo et al. 2010) it was returned back into the genus Campanula, while Raus (2014) included it into the newly established section $C$. sect. Symphyandra (A. DC.) Raus. The closest relatives of $C$. wanneri in the Balkan Peninsula are C. hofmannii (Pant.) Greuter \& Burdet (syn. Symphyandra hofmannii Pant.) distributed in Bosnia and Herzegovina (Redžić 1976, Parić et al. 2015), C. cretica (A. DC.) D. Dietr. (syn. S. cretica A. DC.) from Kriti, C. samothracica (Degen) Greuter \& Burdet ( $\equiv$ S. samothracica (Degen) Halácsy) from Samothraki, C. boreosporadum Raus (syn. S. sporadum Halácsy) from the Northern Sporades and C. orphanidea Boiss. (syn. $S$. pangaea Heldr. \& Charrel) from Mt. Pangeo in NE Greece (Dimopoulos et al. 2013, Raus 2014). 


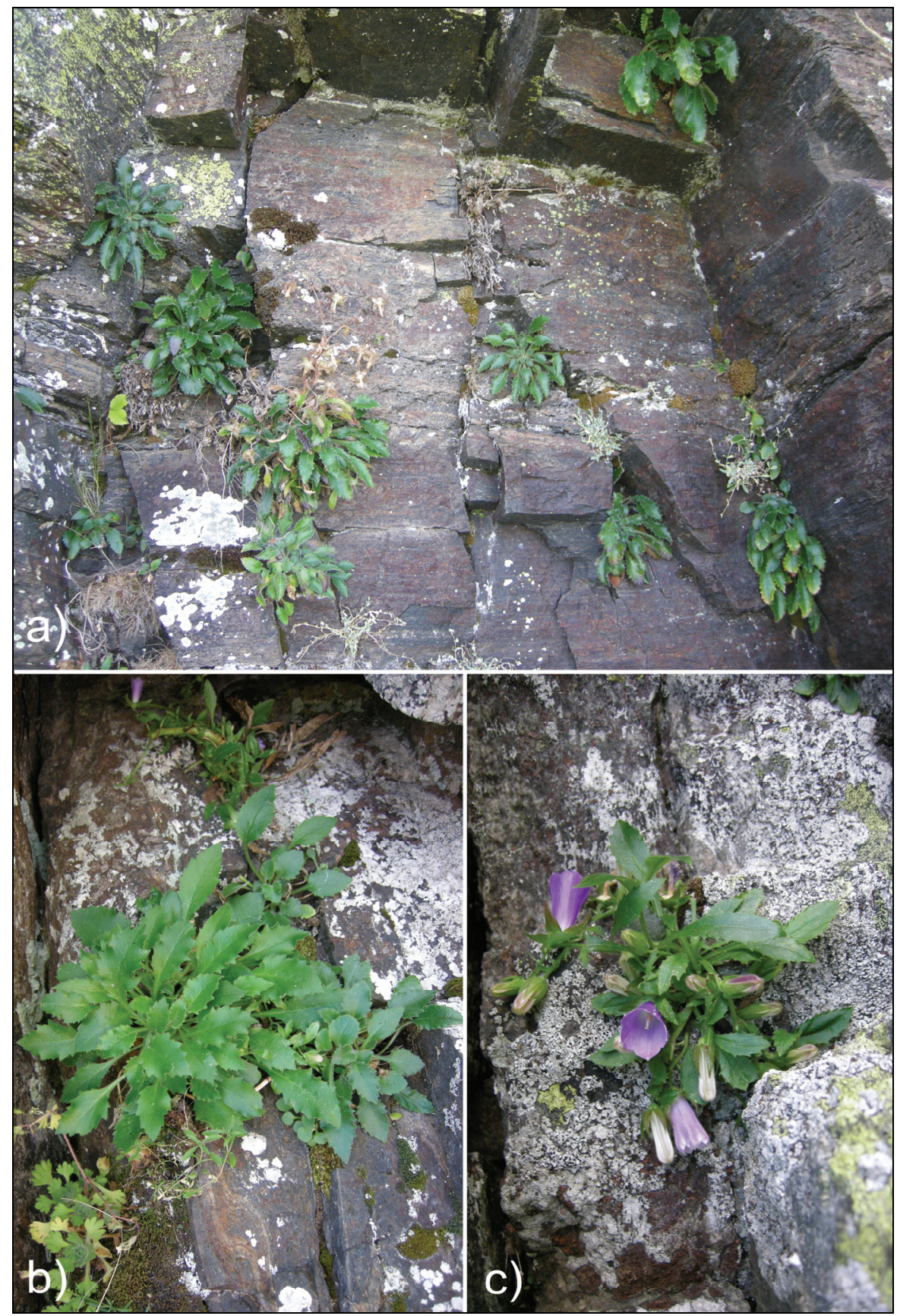

Fig. 1. - Campanula wanneri Rochel in Mt. Jakupica (Korda - Begovi virovi): a) species habitat; b) plant rosette; c) flowering plant (photo G. Tomović). 


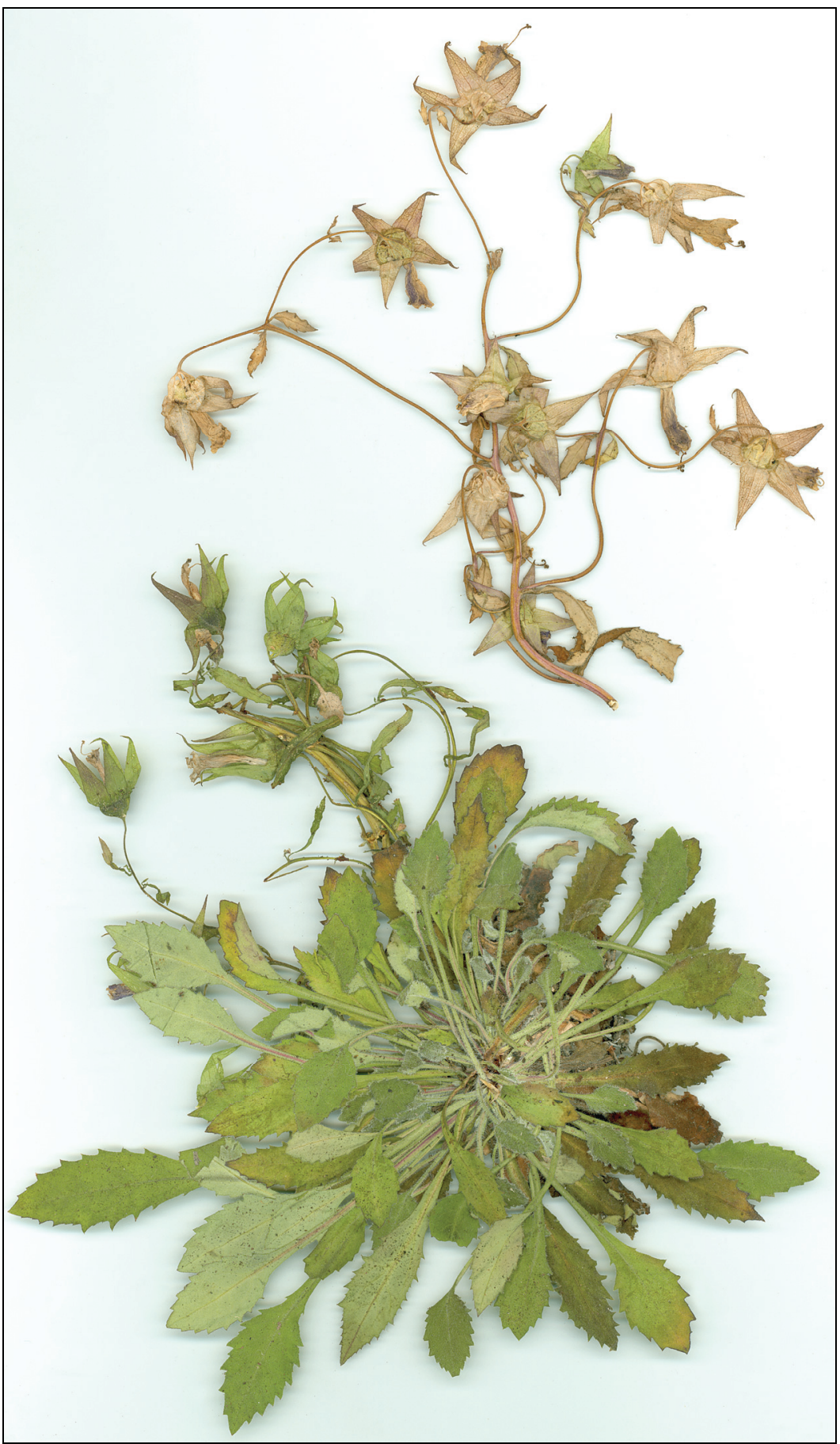

Fig. 2. - Campanula wanneri Rochel - herbarium specimens from Mt. Jakupica (BEO). 


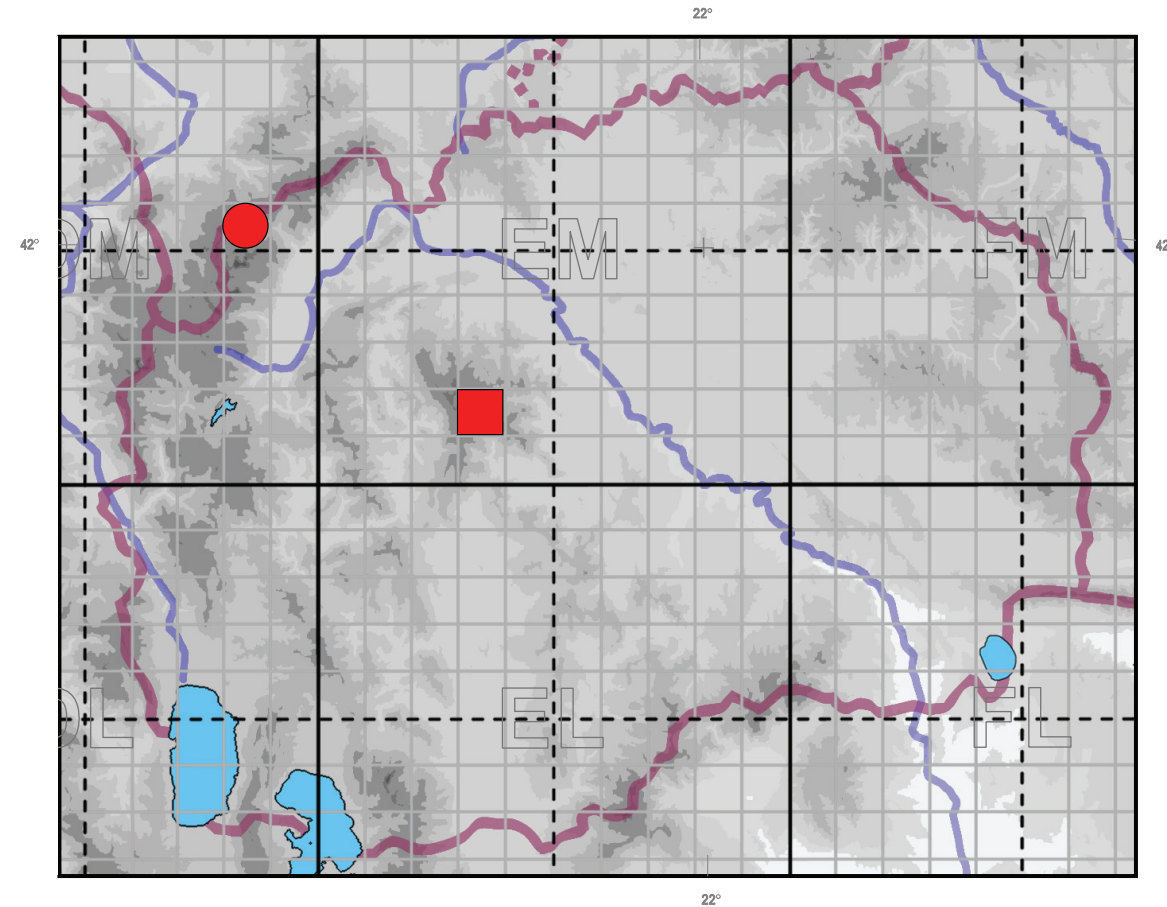

Fig. 3. - Distribution of two new species in the Republic of Macedonia, indication of locations: square - Campanula wanneri Rochel; circle - Carduus ramosissimus Pančić.

C. wanneri is a Balkan-Carpathian subendemic species, distributed in the eastern part of the Balkan Peninsula (Bulgaria, Serbia and Greece) with its northern distribution extending to Romania. In Romania it grows in several regions/localities, but only in the Eastern and Southern Carpathians (Guşuleac 1964, Bartók et al. 2016). In Bulgaria this plant was recorded in the following mountains: Central Rhodopi, Rila, West Frontier Mountains (Mt. Osogovska Planina), Western Predbalkan, Central and Western Stara Planina (Assyov et al. 2012, Ančev 2013). In Serbia it is present only in several localities on Mts Stara Planina (Obradović 1974), while in Greece it is distributed in NC and NE Greece (Mts Central Rhodopes) (Strid \& Papanicolaou 1981, Dimopoulos et al. 2013). Presence of this species in Croatia (Nikolić 2000) should be treated as erroneous.

First record in the Republic of Macedonia: Mt. Jakupica: Korda Begovi Virovi, rock crevices, c. $1550 \mathrm{~m}$, silicate, $21.473830^{\circ} \mathrm{E}$, 41.671544 N, EM31, coll. M. Niketić, G. Tomović, det. G. Tomović, M. Niketić, 24-Jul-2017 (BEOU, 37150; BEO, 20170708) (Fig. 2).

So far there have been no data about the presence of this species in the R. of Macedonia (Bornmüller 1928). The record of C. wanneri on Mt. 
Jakupica represents the westernmost locality of the species distribution range; the closest locality the Mt. Osogovski Planini in eastern Bulgaria, which is c. $100 \mathrm{~km}$ distant from Mt. Jakupica (Fig. 3). At a single locality on Mt. Jakupica this chasmophytic plant is a member of vegetation of siliceous rock crevices at high altitudes that are included in the vegetation alliance Silenion lerchenfeldianae Simon 1958 which is present in the Eastern Carpathians and the Southern Balkans. It can be found at the elevation between $1,500 \mathrm{~m}$ and 2,100 $\mathrm{m}$ a.s.l. in the zone of montane beech forest. Habitat of the species is dominated by the following plant taxa: Campanula wanneri Rochel, Atocion lerchenfeldianum (Baumg.) M. Popp, Silene waldsteinii Griseb., Cytisus hirsutus L., Scrophularia aestivalis Griseb., Asplenium septentrionale (L.) Hoffm., Campanula rotundifolia L., Saxifraga pedemontana subsp. cymosa Engl., etc.

\section{Carduus ramosissimus Pančić - ASTERACEAE (Fig. 4)}

This Balkan endemic species was described by Pančić (1875) from Mt. Durmitor (Crvena Stijena peak) in Montenegro; it also grows on Mt. Orjen (Bijela Gora peak) (Rohlena 1942, Vuksanović 2016). In Bosnia and Herzegovina it can be found on Mt. Trebević, Mt. Prenj (Tisovica peak), Mt. Bjelašnica and Mt. Čvrsnica (Crepulja peak) (Mayer 1983). In Albania and Serbia it grows only in the Prokletije mountains (the Albanian Alps) (Rechinger fil. 1935, Gajić 1975, Tomović 2007, Barina 2017). The closest relative of $C$. ramosissimus is the common ruderal plant $C$. acanthoides $\mathrm{L}$. from which it differs in having longer and denser spines (Amal Franco 1975). Another relative is C. tmoleus Boiss., distributed in E Balkans and Anatolia, which has larger and firmer spines then C. ramosissimus.

First record in the Republic of Macedonia: Mts Šar Planina: E slopes of Mt. Džinibeg towards Krivošija cirque (Fig. 5), screes, c. 1920 m, limestone, $20.780607^{\circ} \mathrm{E}, 42.005532^{\circ} \mathrm{N}$, DM85, coll. M. Niketić det. M. Niketić, 02-Aug-2017 (BEOU, 37150; BEO, 20170801) (Fig. 6).

This species has not been recorded in the R. of Macedonia (Bornmüller 1926) and a new locality of C. ramosissimus in the Šar Planina mountains represents the southernmost record of the species' distribution range; the closest occurrence of the species is situated in the Mts Prokletije, which is c. $70 \mathrm{~km}$ distant from this one (Fig. 3). Earlier record of C. thessalus Boiss. $\&$ Heldr. (currently a synonym of $C$. acanthoides) for adjacent Mt. Kobilica on Šar Planina mountains (Bornmüller 1926) could have actually referred to C. ramosissimus. Typical habitats of this species in Montenegro are high-mountain limestone rocks, rocky grounds and screes on \pm nitrophilous places (Vuksanović 2016), while in Albania it grows in alder and beech 


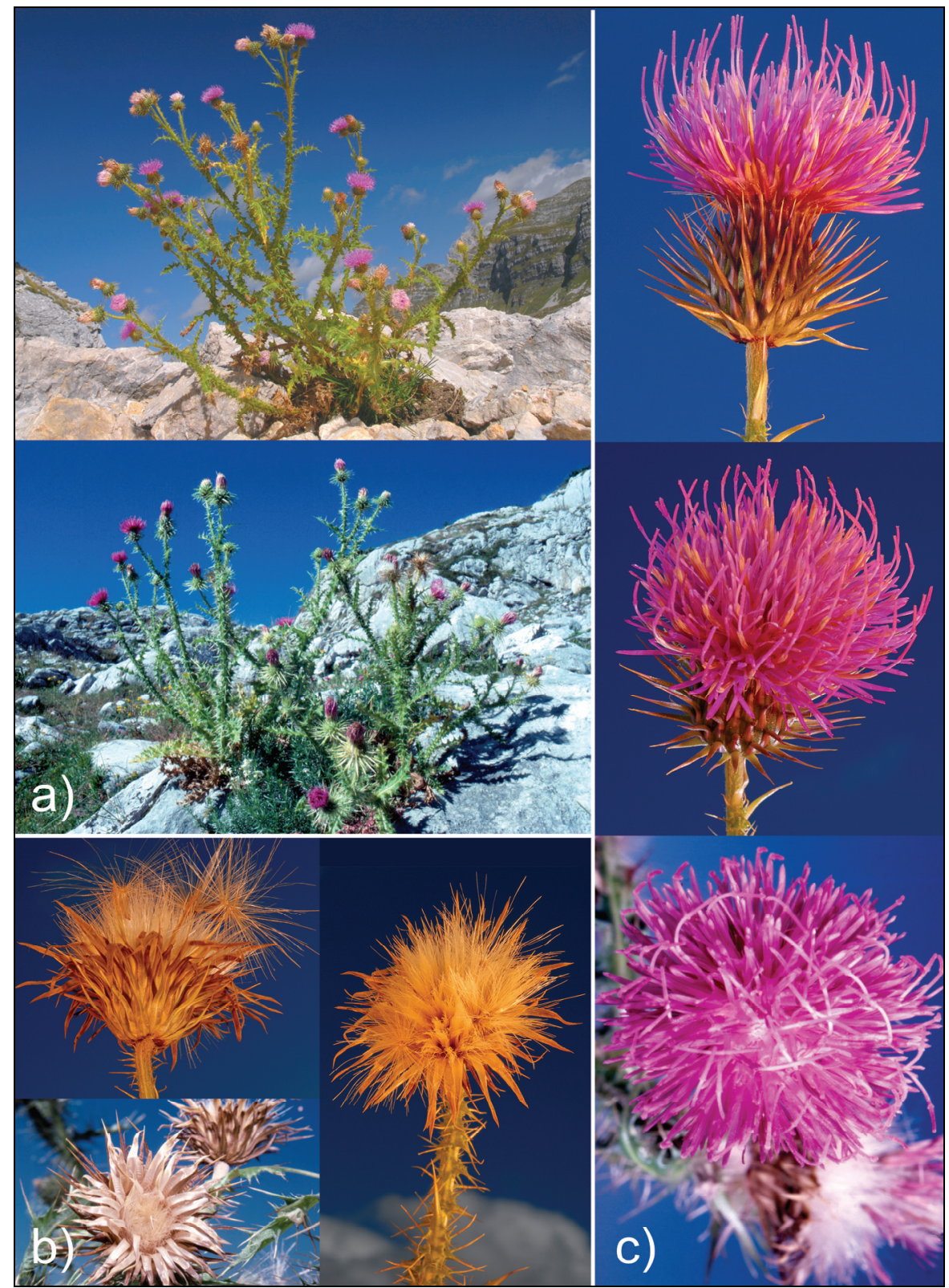

Fig. 4. - Carduus ramosissimus Pančić in Mt. Durmitor (Montenegro): a) habitus; b) capitula in fruit; c) capitula in flower (photo M. Niketić).

forests at the elevation ranging from 1,000 to 1,400 $\mathrm{m}$ a.s.1. (Barina 2017). It has not been recorded for the "serpentine rocks" as it was noted in Amal Franco (1975). Only few individuals were observed at Mt. Džinibeg on limestone screes at the elevation of $1,920 \mathrm{~m}$ a.s.l. together with the 
following plants: Lactuca intricata Boiss., Crepis macedonica Kitan., Drypis spinosa L., Cardamine glauca Spreng. ex DC., Aubrieta scardica (Wettst.) Gustavsson, Silene uniflora subsp. prostrata (Gaudin) Chater \& Walters, etc. On the surrounding limestone rock crevices several species of Hieracium sect. Pannosa Zahn were detected. Similar ecological pattern was also observed in the habitat of $C$. ramosissimus in the SE Dinarides.

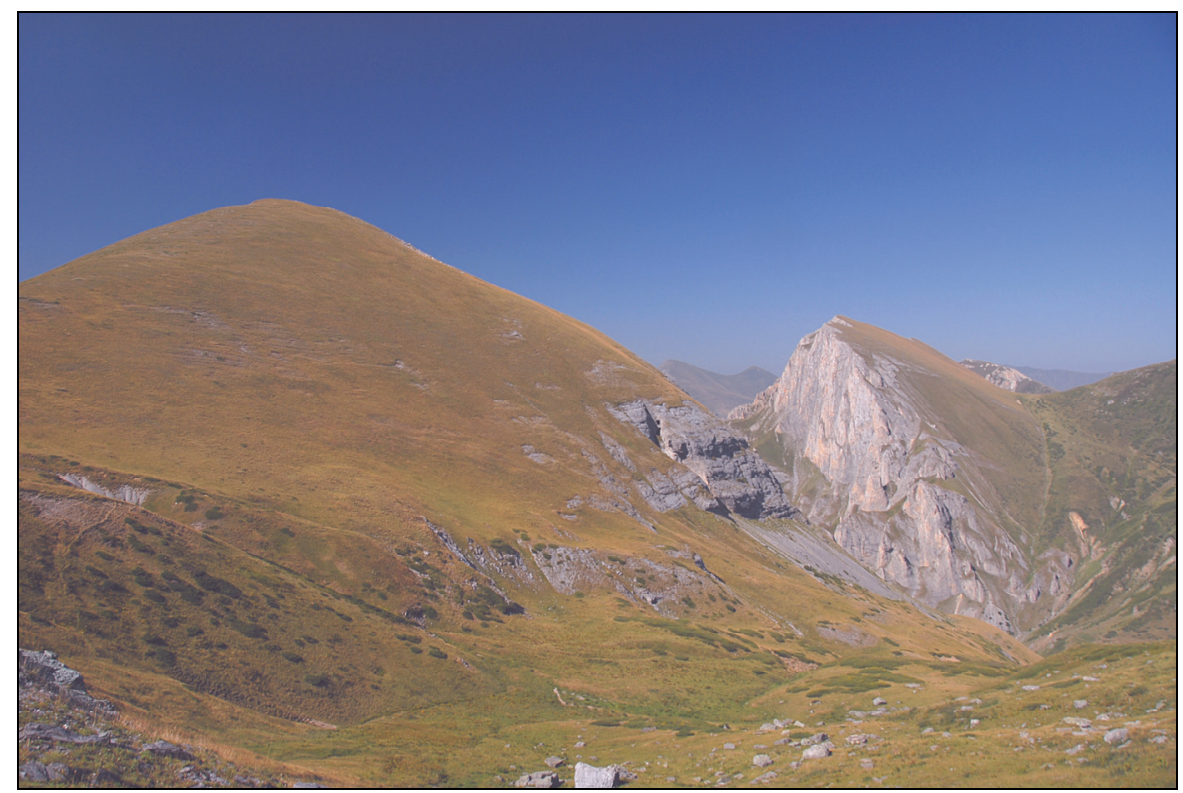

Fig. 5. - Carduus ramosissimus Pančić in Mts Šar Planina (Džinibeg peak towards Krivošije cirque): species habitat (photo M. Niketić).

\section{CONCLUSIONS}

Two plant species were reported as new for the flora of the Republic of Macedonia: Campanula wanneri and Carduus ramosissimus. Very restricted locality of $C$. wanneri on Mt. Jakupica in northern Macedonia is c. 100 $\mathrm{km}$ distant from the nearest known site in eastern Bulgaria (Mts Osogovske Planini) and marks the westernmost limit of the species distribution range in the Balkan Peninsula. New record of C. ramosissimus on Mts Šar Planina represents the southernmost locality of the species distribution range; the nearest locality is situated in the Mts Prokletije, at the distance of c. $70 \mathrm{~km}$. 


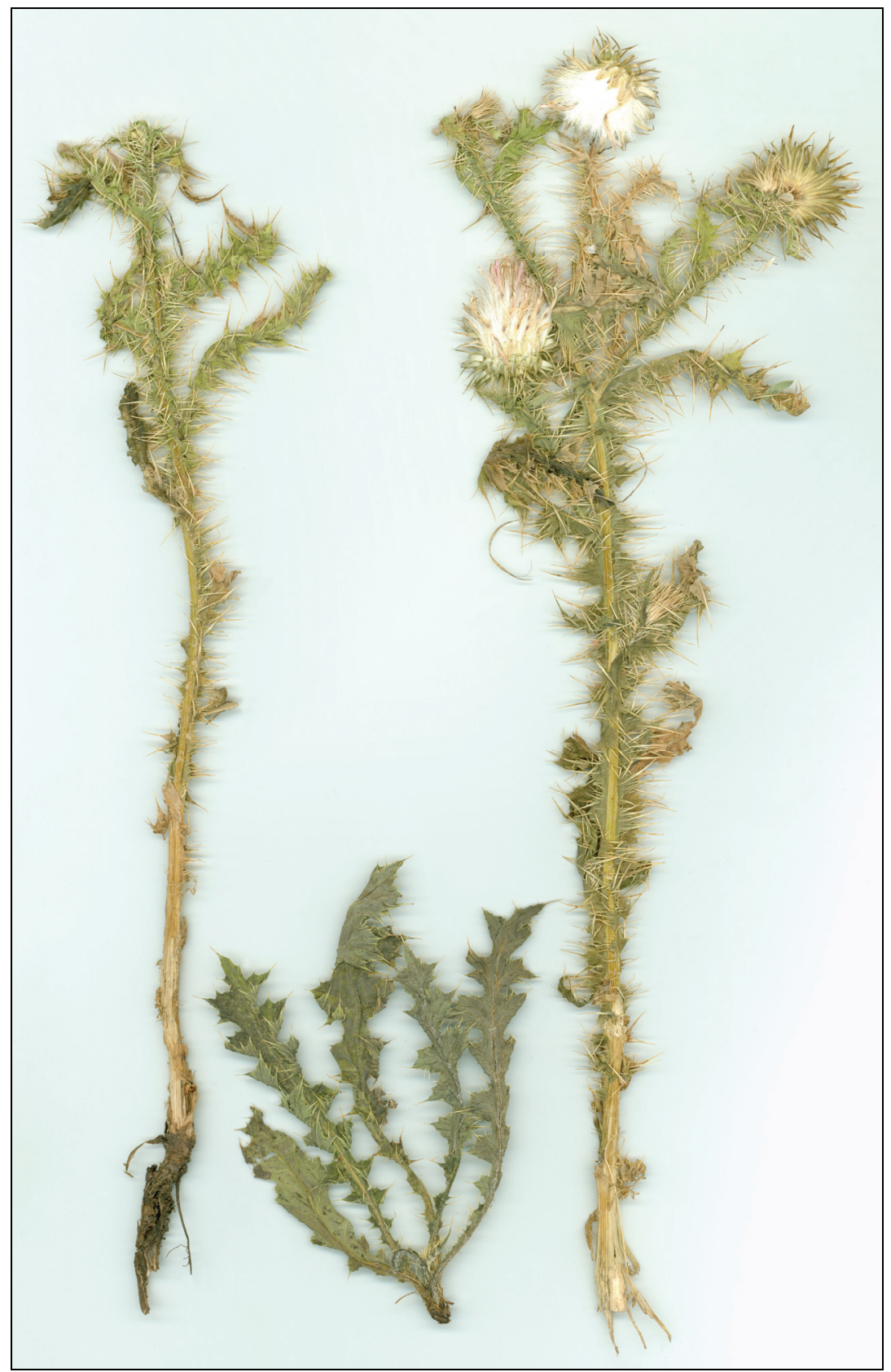

Fig. 6. - Carduus ramosissimus Pančić - herbarium specimens from Mts Šar Planina (BEO). 


\section{Acknowledgements}

The Ministry of Education, Science and Technological Development of the Republic of Serbia supported this research through Grant 173030 "Plant biodiversity of Serbia and the Balkans - assessment, sustainable use and protection". We would like to thank the Macedonian Ecological Society and Biology Students Research Society from the Republic of Macedonia for organising a very successful expedition to Mt. Jakupica in July 2017.

\section{REFERENCES}

Amaral Franco J. (1976): Carduus L. In: Tutin, T. G., Heywood, V. H., Burges, N. A., Moore, D. M., Valentine, D. H., Walters, S. M., Webb, D. A. (eds): Flora Europaea 4: 220-232. - Cambridge University Press, Cambridge.

Ančev, M. E. (2013): Campanulaceae Adans. In: Kožuharov, S. I., Ančev, M. E. (eds): Flora Reipublicae Bulgaricae 11: 84-159. - Bălgarskata Akademija na Naukite, Sofija. [in Bulgarian].

Assyov, B., Petrova, A., Dimitrov, D., Vassilev, R. (2012): Conspectus of the Bulgarian vascular flora. Distribution maps and floristic elements. ed. 4 Bulgarian Biodiversity Fondation, Sofia.

Barina, Z. (ed.) (2017): Distribution atlas of vascular plants in Albania. Hungarian Natural History Museum. Budapest.

Bartók A., Hurdu B.-I., Szatmari P.-M., Ronikier M., Puşcaș M., Novikoff A., Bartha L., Vonika G. (2016): New records for the high-mountain flora of the Făgăraş Mts. (Southern Carpathians) with discussion on ecological preferences and distribution of studied taxa in the Carpathians. - Contribuţii Botanice 51: $77-153$.

Bornmüller, J. (1926): Beiträge zur Flora Mazedoniens II. - Sammlungen in den Kriegsjahren 1916-1918. - Botanische Jahrbücher für Systematik, Pflanzengeschichte und Pflanzengeographie 60(136): 1-125.

Bornmüller J. (1928): Beiträge zur Flora Mazedoniens III. - Sammlungen in den Kriegsjahren 1916-1918. - Botanische Jahrbücher für Systematik, Pflanzengeschichte und Pflanzengeographie 61(140): 1-195.

Castroviejo, S., Aldasoro, J. J., Alarcón, M., Hand, R. (2010): Campanulaceae. In: Euro+Med (2006-): Euro+Med PlantBase - the information resource for Euro-Mediterranean plant diversity. Published on the Internet http://ww2. bgbm.org/EuroPlusMed/ [accessed 10-Jul-2017].

Dimopoulos, P., Raus, Th., Bergmeier, E., Constantinidis, Th., Iatrou, G., Kokkini, S., Strid, A., Tzanoudakis, D. (2013): Vascular plants of Greece: An annotated checklist. - Botanischer Garten und Botanisches Museum, Berlin-Dahlem; Hellenic Botanical Society, Athens.

Gajić, M. (1975): Asteraceae Dumortier In: Josifović, M. (ed.). Flora SR Srbije. 7: 1-465. - Srpska akademija nauka i umetnosti. Beograd. 
Greuter, W. (2006-): Compositae (pro parte majore). In: Greuter, W., Raab-Straube, E. von (eds): Compositae. Euro+Med Plantbase - the information resource for Euro-Mediterranean plant diversity. Published on the Internet http://ww2.bgbm.org/EuroPlusMed/ [accessed 10-Jul-2017].

Guşuleac, M. (1964): Campanulaceae. In: Săvulescu, T. (ed.): Flora Republicii Populare Române 9: 52-149. - Academia Republicii Populare Române, Bucuresti.

Heuffel, J. A. (1858): Enumeration plantarum Banatus Temesiensis. - Verhandlungen der Zoologisch-Botanischen Gesellschaft in Wien 8: 39-240.

Matevski, V. (2016): New species for the flora of the Republic of Macedonia. Contributions, Section of Natural, Mathematical and Biotechnical Sciences, MASA, 37(2): 79-83.

Matevski, V., Teofilovski, A. (2004): Novi prilozi za floratana Republika Makedonija. In: Zbornik na trudovi od IIkongres na ekolozite na Makedonija so medjunarodnoučestvo, Skopje. - Posebni izdanija na Makedonsko ekološko društvo, Kn. 6: 384-389.

Matevski, V., Teofilovski, A. (2011): New species in the Flora of the Republic of Macedonia. - Biologia Macedonica 62: 49-54.

Mayer, E. (1983): Tribus Cardueae Cass. In: Bjelčić, Ž. (ed.). Flora Bosnae et Hercegovinae IV Sympetalae 4: 90-115. - Zemaljski muzej BiH. Sarajevo.

Melovski, Lj. (2016): The genus Dryopteris (Pteridophyta: Dryopteridaceae) in the flora of the Republic of Macedonia. 30 years after Micevski's flora. Contributions, Section of Natural, Mathematical and Biotechnical Sciences, MASA 37(2): 85-93.

Melovski, Lj., Hristovski, S. (2015): First records for seven species and one hybrid for the flora of The Republic of Macedonia. - Forest Revew 46: 36-42.

Nikolić, T. (2000): Flora Croatica. Index florae Croaticae, 3. - Natura Croatica Zagreb 9, Suppl. 1.

Obradović, M. (1974): Campanulaceae. In: Josifović, M. (ed.): Flora SR Srbije 6: 528-573. - Srpska Akademija nauka i umetnosti, Beograd.

Pančić, J. (1875): Elenchus plantarum vascularium quas aestate a. 1873 in Crna Gora. - Edidit Societas Erudita Serbica, Belgrade.

Parić, A., Karalija, E., Pustahija, F., Šiljak-Yakovlev, S., Muratović, E. (2015): Pigments and genome size variation in Symphyandra hofmannii population. Bulletin of the Chemists and Technologists of Bosnia and Herzegovina 44: 71-78.

Raus, Th. (2014): Campanulaceae. In: Raab-Straube E. von \& Raus Th. (eds): Euro+Med-Checklist Notulae, 3: 288-289. - Willdenowia 44(2): 287-299.

Rechinger, K. H. fil. (1935): Ergebnisse einer botanischen Reise in den Bertiscus (Nordalbanische Alpen). - Feddes Repertorium specierum novarum regni vegetabilis 38(13-25): 138-152; 319-389.

Redžić, S. (1976): O bosanskoj zvončiki. - Biološki List 24: 117-118.

Rochel A. (1828): Plantae Banatus Rariores Iconibus et Descriptionibus Illustratae. - Typis Ludovici Landerer de Füskút, Pestini. 
Strid, A., Papanicolaou, K. (1981): Floristic notes from the mountains of Northern Greece: Materials for the Mountain Flora of Greece, 7. - Nordic Journal of Botany 1(1): 66-82.

Teofilovski, A. (2011): Prilozi za florata na Republika Makedonija. - Private edition, Skopje.

Teofilovski, A. (2017): Contribution to knowledge of the flora of the Republic of Macedonia. - Botanica Serbia 41(1): 99-103.

Thiers, B. (2017) [continuously updated] Index Herbariorum: A global directory of public herbaria and associated staff. New York Botanical Garden's Virtual Herbarium. Available from: http://sweetgum.nybg.org/ih/

\author{
ДВЕ НОВЕ ВРСТЕ ЗА ФЛОРУ РЕПУБЛИКЕ МАКЕДОНИЈЕ \\ МАРЈАН НИКЕТИЋ, ЉУПЧО МЕЛОВСКИ, ВЛАДО МАТЕВСКИ, \\ ГОРДАНА ТОМОВИЋ
}

\title{
Р Е 3 И М Е
}

Током две ботаничке екскурзије у Републици Македонији у 2017. години (Шар-планина и Јакупица) нађене су две нове васкуларне биљке за флору ове територије: Campanula wanneri Rochel на Јакупици и Carduus ramosissimus Pančić на Шар-планини. Дати су прецизни подаци о њиховим локацијама, описи станишта, као и осврт на фитогеографски значај нових налазишта. 